\title{
Viewpoint
}

\section{Eastern Nevada Landscape Coalition Position}

\section{There are consequences of doing nothing in natural resource management. What are they?}

\author{
By Barry L. Perryman, Robert E. Wilson, and William I. Morrill
}

Fire disturbance has played an integral role in the ecology and development of semi-arid plant communities throughout western North America. Altered fire intervals and regimes since European settlement have led to pervasive alterations in species richness, diversity, fuel loads, and associated processes such as nutrient cycling and biogeochemistry within native rangeland plant communities.

Disruptions have occurred at multiple spatial and temporal scales. Consequently, values prized by society such as water quality and quantity, minimal soil erosion, wildlife and domestic animal habitat (including sagebrush and other obligate species), and ecological integrity have been compromised to varying degrees. This is particularly true in the sagebrush ecosystems of the western U.S.

Fire intervals and regimes changed in the late 1800 s during European settlement as a result of newly imposed grazing systems for domestic animals, introduction of exotic plant species, construction of fire breaks (e.g., roads, crop agriculture), and fire suppression activities. Consequently, fire frequency, severity, seasonality, and spatial extent have changed.

For example, at the higher elevations and moisture levels (e.g., sagebrush-grassland communities), lengthened fire intervals have resulted in pinyon and/or juniper encroachment. This has led to progressive decreases in fine fuels while increasing woody fuel loads.

Species richness and diversity decline dramatically as overstory canopies close. In contrast, the lower elevation, drier communities (i.e., Wyoming big sagebrush-grasslands and salt desert shrub communities) have been invaded by exotic annual grasses (e.g., cheatgrass) resulting in increases in fine fuels, decreases in woody fuels and increased fire frequency.

Cumulative non-ecological results in both of these situations are an increased risk to human life and property, and incredibly high fire management costs.

\section{Two Primary Concerns}

Two major problems resulting from past fire suppression activities are common to the sagebrush ecosystem:

1) Longer time periods between fires (lengthened fire intervals) at higher elevations (higher precipitation zones) have allowed various junipers and/or pinyon pines to encroach into mountain sagebrushgrassland communities.

In the Great Basin, juniper and pinyon are relatively long-lived species (approximately 1,000 and 600 years, respectively). Depending on specific location, U.S. Forest Service researcher Robin Tausch estimates that 66 to over $90 \%$ of individual trees are less than 130 years old. Fire return intervals have increased from 12-25 years to over 100 years.

These communities lose the perennial herbaceous and shrub understory as the canopy closes in large part due to competition from the encroaching conifers. This encroachment further leads to unmanageable fuel loads and very intense fires resulting in final loss or elimination of perennial understory species, and loss of the original sagebrush habitat.

Without a healthy understory, these disturbed communities become susceptible to annual brome or other invasive species establishment, further reducing habitat quality for sagebrush obligates and other species both wild and domestic, that utilize sagebrush habitats. 


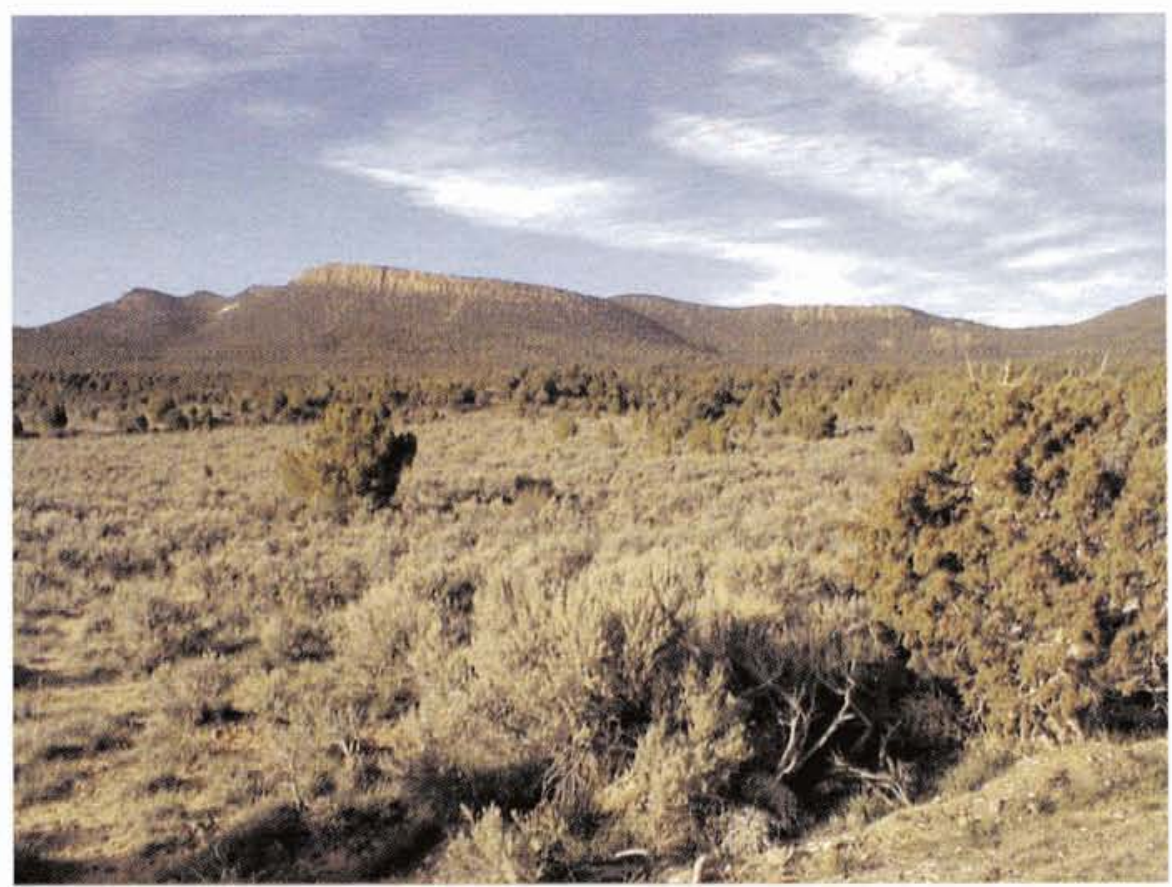

Initial pinyon-juniper encroachment into a sagebrush community.

2) At mid and lower elevations, longer fire intervals have created decadent, climax sagebrush systems that dominate very large areas on the landscape.

These communities have lost the perennial herbaceous understory in large part due to competition from dense competitive sagebrush plants. The shrub overstory in these systems is continuous and contiguous leading to fuel continuities that burn hotter and more extensively than normal.

These areas have also been invaded by the introduced annual brome, "cheatgrass." This species is very successful since there are no perennial, herbaceous species to compete with. After extensive fires in these systems, cheatgrass proliferates even more because fire removes sagebrush (and other shrubs), the only competitor in the system. As fire intervals become shorter due to the fuel loading of the annual brome, areas that a single generation ago were sagebrush grasslands, can be converted to annual grasslands dominated by non-indigenous species.

The geographic scale of these problems is overwhelming. Millions of acres are currently in need of fire/fuel management and rehabilitation/restoration treatments. These problems are common to much of Nevada, including much of White Pine County.

\section{Consequences Today}

Plant community succession is a dynamic process that occurs even in "hands-off" management situations. The endpoint of the successional process is not a static condition, it is in reality a cliff from which the community can fall, leading to disastrous ecological results. Consequences of doing nothing are not acceptable societal values.

Intervention in the successional process allows society to maintain options for the future. For instance, if we continue to allow encroachment and canopy closure of pinyon/juniper communities into sagebrush communities, understory species (including both sagebrush and herbaceous species) will disappear because they cannot compete with the conifers for water, nutrients, and light.

As these plants die off, bare ground increases under the conifer canopy. Bare ground is highly susceptible to erosion. A single, major precipitation event will move millions of tons of topsoil into stream and riparian systems, reducing water quality everywhere downstream of the source.

Bare ground is also highly susceptible to invasion by annual brome grasses and other noxious weeds. Disturbed areas are always colonized by weedy species, and when there are no native perennial species to act as a competitive buffer, introduced an- 


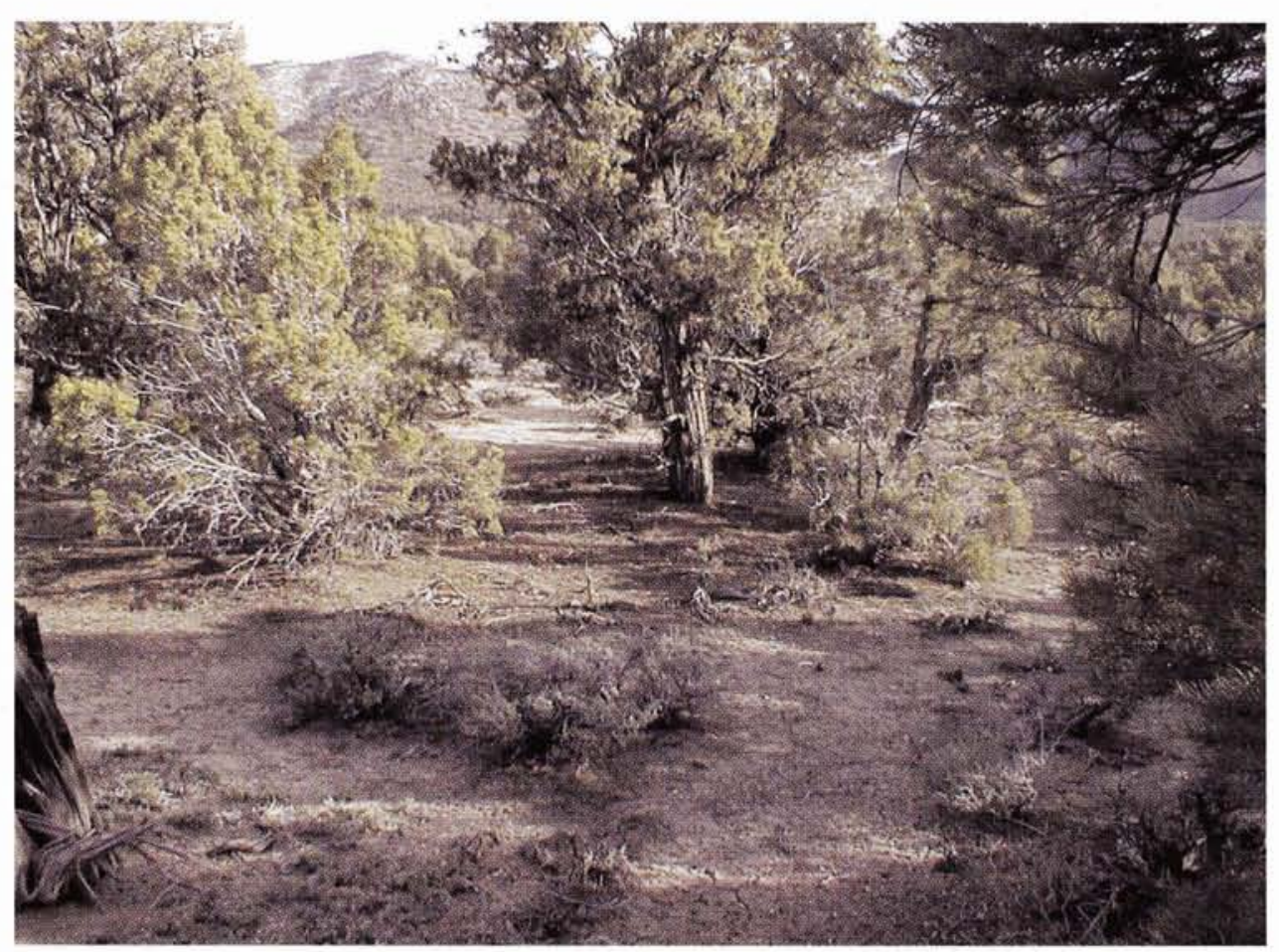

Late encroachment stage with corresponding disappearance of understory vegetation.

nuals (cheatgrass) will proliferate to a point where only inputs with extremely high economic costs (reseeding etc.) will mitigate the situation. In both scenarios, management and value options are limited.

Without topsoil, we cannot expect the area to return to a similar sagebrush ecosystem without extreme mitigation measures, (unless a several thousand year time period is acceptable to our society!).

An annual grassland will not recover and return to a sagebrush ecosystem without tremendously expensive inputs and several decades of time. If the ecological potential of a site is lowered, management and value options are decreased. For example, we cannot manage for some types of sage grouse habitat if we have no topsoil on a given area or if the area is an annual brome grassland.

Intervention in the successional process through management of introduced fire or other means allows society to maintain management and societal value options for the future.

\section{The Successional Process}

Natural resource or land management is the manipulation of the successional process so the resource can provide the qualities, products, and val- ues society desires. As land managers we can only accelerate and direct succession. We accelerate it by introducing propagules into disturbed areas rather than waiting for natural processes such as seed rain to occur.

We direct succession by introducing disturbances such as fire and herbivory to achieve plant community compositions that provide products or services determined by society.

Ecologists and land managers understand that a diverse landscape (in terms of the mix of different plant community types and species within those communities) provides more opportunities to achieve the objectives that society desires. In the sagebrush ecosystem, we currently have a homogenous situation rather than the heterogeneous one we desire.

Current conditions are a result of many past management practices, in particular fire suppression. Fires have been passively suppressed since European settlement by alterations in fuel loads and establishment of roads, and actively suppressed since about 1940 when motorized vehicles and aircraft with capacities to haul large quantities of water became available. For the previous 2.5 million years (since the beginning of the Pleistocene), fire was prevalent on the landscape, initiated by 
both natural and for the last several millennia, anthropic ignitions by Native Americans. Fire was a "natural" intervening disturbance in the successional process, periodically removing woody vegetation such as sagebrush and pinyon/juniper, effectively setting the successional process back a few stages. Succession would then move back to stages that supported more woody vegetation, and so the process continued with this cyclic nature providing a heterogeneous landscape.

Land managers have, over the past several decades suppressed fires, effectively allowing succession to proceed to a point where we now have millions of acres supporting plant communities that are in very late seral stages, dominated or encroached by woody species. Many of these sagebrush communities have crossed successional thresholds (e.g., loss of the perennial, herbaceous understory) that will require additional inputs of energy and dollars to accelerate and direct succession in a way that society desires. We have created a homogeneous landscape that now threatens to limit our management options, reducing our ability to provide ecosystem services valued by society.

We suppressed fire for the past several decades with the approval of society because we wanted what the landscape gave us at that time. In the past we were influenced by the pristine-management-paradigm, the idea that ecological systems were static entities that could be held in a static condition if we protected them from burning and other disturbances.

We desired a condition that resembled the landscape at the time of European settlement. We now know this was an impossible goal.

We cannot go back to the conditions in $1850 \mathrm{AD}$. However, active dynamic disturbance regimes prior to European settlement created the landscape that fostered the values so highly prized by our society.

Plant communities do not develop to a point and become static. They continue to develop and change until some disturbance (e.g., fire) sets the successional process back to earlier stages. If we are talking about successional time scales, recovery and change are inevitable. However, centuries and millennial time scales are not acceptable to society.
We must intervene in the successional process on millions of acres before succession develops stages that are too expensive or beyond our technological abilities to mitigate in a reasonable time scale.

We must manage the landscape instead of taking the protection course we have been pursuing for the past several decades. By protecting it from disturbance, we severely limit or destroy our options for the future.

To be successful in this endeavor, we as a society must begin to initiate a paradigm shift with respect to our management of these lands. Past management approaches have generally been reactive. For example, large burn areas in recent years have received concentrated, intense rehabilitation efforts. The merits of fire rehabilitation are unchallenged and should continue.

However, reactive management activities have dominated land management practice while little attention has been given to proactive management. We must begin to intervene in the successional process rather than rely entirely on reactive activities and their associated funding.

We must overcome the institutional inertia within our society, government, and land management agencies that is dedicated to the reactive management approach. We must allow disturbances to be active and manageable on the landscape. In order to achieve this paradigm shift, we must be more proactive in our management strategies.

Between 1994 and 1999, the U.S. taxpayer paid $\$ 2,972,473,600$ in fire suppression costs. Reducing fire suppression efforts by only $25 \%$ would have provided a savings of approximately $\$ 743$ million over the 6-year period. Funds that could have been invested in restoration activities to further reduce fire management costs. Over 19 million acres burned during the period. As a result, many of these acres were converted to annual grasslands that will require additional funds for rehabilitation and restoration activities.

The Nature Conservancy and others list invasive species as the second leading cause of species endangerment nationwide. About $42 \%$ of all federally threatened or endangered species are listed because 
of threats from invasive plants. Neil West, Utah State University, estimates that $25 \%$ of the original sagebrush ecosystem is now an annual cheatgrass/medusa-head rye grassland, and an additional $25 \%$ of the sagebrush ecosystem has only cheatgrass as an understory constituent. Annual grass invasions may only be the first wave; perennial invasive species are already making serious inroads into adjoining states and Nevada as well. Potential subsequent domination by perennial invasive species will virtually eliminate any resource values for society.

Other costs of not changing our management approach, or the costs of doing nothing include: accelerated loss of topsoil, reduced water quality and quantity, riparian zone degradation, loss of riparian zone and wetland area, loss of wildlife and domestic animal forages and habitats, loss of wildlife and plant species, loss of species richness and abundance in general, loss of aesthetic appeal, loss of recreation potential, loss of western and Native American cultural values and life ways, loss of civic communities, economic depression in rural areas, loss of carbon sequestration potential, opportunity costs of fire suppression activities, lowered air quality, perhaps loss of life and property, loss of a source of national pride and environmental influence in the world community.

This trend cannot continue if we wish to preserve our options for the future. We must change our management paradigm, we must intervene in the successional process across millions of acres on our western rangelands or future generations will inherit a landscape devoid of many of the values we now enjoy.

Note: Viewpoints expressed are those of the individual authors and not the entire SRM membership.

\section{Other Reading}

Tausch, R.J. 1999. Historic pinyon and juniper woodland development. In: Monsen, S.B. and Stevens, R., comps. Proceedings: ecology and management of pinyon-juniper communities within the Interior West; 1997 Sept 15-18; Provo, UT. Proc. RMRS-P-9. Ogden, Ut: USDA Forest Serv., Rocky Mountain Res. Stat.

West, N.E. 1999. Synecology and disturbance regimes of sagebrush steppe ecosystems. Pp. 15-26 in Entwistle, P.G., A.M. DeBolt, J.H. Kaltenecker, and K. Steenhof, compilers. Sagebrush Steppe Ecosystems Symposium. BLM Pub. No: BLM/ID/PT-001001+1150. Boise, Id.

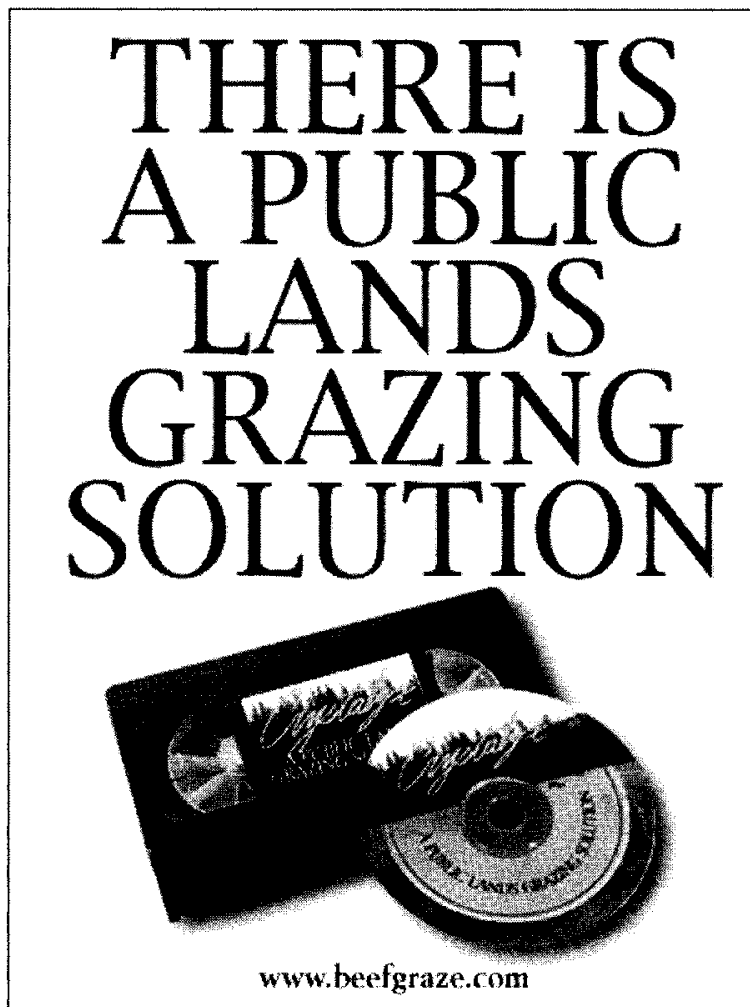

Find out how it can work for you.

This FREE video will describe to you recent research about a proven solution for grazing public lands using CRYSTALYX Brand Supplements.

Applied appropriately, you can maintain and possibly increase your AUM's harvested.

To order your FREE video, DVD or CD-ROM and a six-page Public Lands article, call $1-866-635-3718$ or go to www.beefgraze.com.

Take the first step by submitting your request to: www.beefgraze.com or call 1-866-635-3718

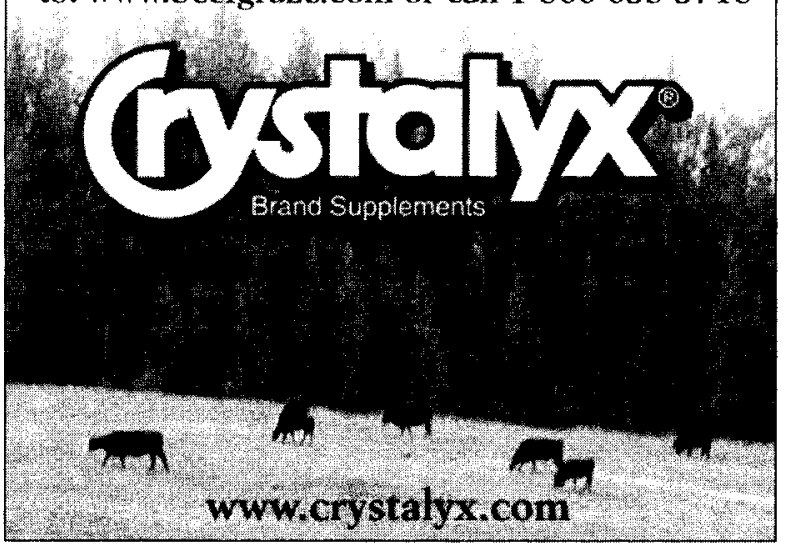

